1 - ORIGINAL ARTICLE WOUND HEALING

\title{
Influence of arterial hypertension on colonic healing in rats ${ }^{1}$
}

\section{Influência da hipertensão arterial na cicatrização colônica em ratos}

\author{
Gilberto Luiz Ortolan', Maria de Lourdes Pessole Biondo-Simões", Giovani Marino Fávero ${ }^{\text {III }}$, Daniel Fernandes ${ }^{\mathrm{III}}$, Mário \\ Rodrigues Montemór Netto ${ }^{\mathrm{IV}}$, Luiz Renato Olchanheski JrV
}

IFellow Master degree, Postgraduate Program in Surgery, PUCPR, Parana, Brazil. Involved in experimental phases, acquisition and interpretation of data, manuscript preparation.

IIFull Professor, Department of Surgery, PUCPR, Associate Professor, Department of Surgery, Federal University of Parana (UFPR), Brazil. Conception and design, supervised all phases of the study, manuscript writing, critical revision.

IIIPhD, Associate Professor, Department of Pharmaceutical Sciences, UEPG, Ponta Grossa-PR, Brazil. Helped with technical procedures, acquisition of data, critical revision.

IV Pathologist, Department of Pathology, Santa Casa de Misericordia de Ponta Grossa, Parana. Histopathological examinations.

${ }^{\vee}$ Graduate student, Pharmacy Faculty, UEPG, Ponta Grossa-PR, Brazil. Helped with technical procedures and acquisition of data.

\section{ABSTRACT}

PURPOSE: Evaluation of colonic healing in spontaneously hypertensive rats.

METHODS: Fifty male, young and inbred rats were used. Twenty-five Wistar Kyoto rats (WKY) as control and twenty-five spontaneously hypertensive rats (SHR) as an experimental group. Colotomy and bowel suture at $2.5 \mathrm{~cm}$ from the peritoneal reflection were performed. All animals were allocated randomly into sub-groups for review at the third, seventh and fourteenth days after surgery. We evaluated the concentration of angiotensin II, the burst pressure, epithelialization, the organization of the tunics of the bowel wall, inflammatory response and collagen deposition.

RESULTS: The burst pressure, epithelialization, organization of the tunics and collagen deposition was not significant between groups. The inflammatory reaction was more intense in the control group on the third postoperative day $(\mathrm{p}=0.023)$ as the experimental group on the remaining time.

CONCLUSION: Systemic arterial hypertension in rats did not influence significantly the healing process of colonic anastomoses.

Key words: Wound Healing. Colon. Hypertension. Rats, Inbred SHR.

\section{RESUMO}

OBJETIVO: Avaliar a cicatrização colônica em ratos espontaneamente hipertensos.

MÉTODOS: Cinquenta ratos machos, jovens e isogênicos. Vinte e cinco ratos da linhagem Wistar Kyoto (WKY) como controle e vinte e cinco ratos espontaneamente hipertensos (SHR) como grupo experimento. Realizou-se colotomia e colorrafia a $2,5 \mathrm{~cm}$ da reflexão peritoneal. Alocaram-se os animais aleatoriamente em sub-grupos para avaliação no terceiro, sétimo e décimo quarto dias de pósoperatório. Foram avaliados a concentração de angiotensina II, a resistência da anastomose à insuflação, a epitelização, a organização das túnicas da parede intestinal, a reação inflamatória e a deposição de colágeno.

RESULTADOS: A avaliação da resistência da anastomose, epitelização, organização das túnicas e deposição de colágeno não foi significativa entre os grupos. A reação inflamatória foi mais intensa no grupo controle na avaliação do terceiro dia de pós-operatório $(\mathrm{p}=0,023)$ igualando-se ao grupo experimento nos demais tempos.

CONCLUSÃO: A hipertensão arterial sistêmica, em ratos, não influenciou de forma significante no processo cicatricial de anastomoses do cólon.

Descritores: Cicatrização. Cólon. Hipertensão. Ratos Endogâmicos SHR. 


\section{Introduction}

The anastomosis dehiscence is an important factor of morbidity and mortality in colorectal surgery. The healing is a similar process in all tissues, although the initial inflammatory response after injury, deposition of new collagen and subsequent maturation of the scar varies from tissue to tissue with differences in their evolution ${ }^{1}$.

Several works found that angiotensin II, via AT1 receptor, stimulates expression of transforming growth factor- $\beta 1$ (TGF- $\beta 1$ ), resulting in modification of the fibroblast to myofibroblast phenotype and contributing to tissue remodeling, wound healing, accelerates the proliferation and migration of keratinocytes and myofibroblasts ${ }^{2}$, and induce angiogenesis in healing skin ${ }^{3}$.

Some studies observed that the Brazilian average age had increased to 72.7 years in 2008. Global average age had reached to 67.2 years in $2008^{4}$. Hypertension $(\geq 140 / 90 \mathrm{mmHg})$ has a prevalence of $22.3 \%$ to $43.9 \%$ in the Brazilian population ${ }^{5}$ and $48.9 \%$ in the USA population aged up to 65 years old 6 .

As the same time, with the increased prevalence of hypertension in patients over 60 years, this population has become a high risk group for developing colorectal cancer and has undergo surgical treatment. In Brazil, during the period 20042008 , colorectal cancer occupied the fifth position as a cause of cancer death among men and third among women ${ }^{7}$. It is estimated that there will be 30.140 new cases of colon and rectum cancer in Brazil in 2012, being 14.180 men and 15.960 women $^{8}$. The Sao Paulo State, in 2007, there were 6.295 colorectal cancer patients subject to chemotherapy and radiotherapy procedures performed by SUS (Unified Health System). It was observed that the average age was 60 years, which give us an idea the age group that is affected by this disease ${ }^{9}$.

Considering: a) the increase of life expectancy; b) the higher prevalence of hypertension in elderly population; c) colorectal cancer affects this age group and d) the literature is not clear if there are healing changes in the intestine, especially in the colon, we decide to evaluate the influence of hypertension on colonic healing.

It is not easy to separate the limiting of influence of aging and hypertension over the healing process. Thus, the aim of this study is to evaluate the healing of colonic young adult spontaneously hypertensive rats.

\section{Methods}

The study was approved by the Ethics Committee on Animal Use at the Pontificial Catholic University of Parana under the number 510/2010. The protocol obeyed the Brazilian Federal Law No. 11794 of October 8, 2008.

Briefly, twenty-five NTacUnib: WKY Wistar Kyoto rats constituted the control group (C). They are normotensive line, with ages ranging between 114 and 115 days and average weight $327.5 \pm 14.7 \mathrm{~g}$. The experimental group (E) was constituted by twenty-five Wistar Kyoto rats. They are isogenic and genetically hypertensive line SHR / NTacUnib (SHR). The age of the animals ranging between 107 and 114 days and average weight of $264.6 \pm 8.7 \mathrm{~g}$. The animals were obtained from the Multidisciplinary Center for Biological Research in Science Laboratory Animals (CEMIB) State University of Campinas (UNICAMP) and were housed in groups of four to five per box of polypropylene in light/dark cycle of 12 hours, ambient temperature of $22 \pm 2^{\circ} \mathrm{C}$ and humidity was the general environment. Water and standard commercial food were $\mathrm{ad}$ libitum.

After an adaptation of period, animals were allocated randomly into sub-groups based on days after surgery: control $(\mathrm{C})$ and surgery experimentation (E): C3, C7, C14, E3, E7 and E 14.

\section{Surgical procedure}

The animals were anesthetized with an intramuscular injection of $0.1 \mathrm{ml} / 100 \mathrm{~g}$ body weight of a solution consisting of $1.0 \mathrm{ml}$ of ketamine $(50 \mathrm{mg} / \mathrm{ml})$ and $1.0 \mathrm{ml}$ xylazine $(20 \mathrm{mg} /$ $\mathrm{ml}$ ) as well as intra peritoneal $20 \mathrm{mg} / \mathrm{kg}$ thionembutal.

The procedure was a four $\mathrm{cm}$ suprapubic midline incision, colostomy and suture end to end $2.5 \mathrm{~cm}$ above the peritoneal reflection in a single plane, seromuscular, with eight suture points of interrupted 6-0 monofilament nylon and vascular needle of $1.7 \mathrm{~cm}$, closed with four semi-us, aided by surgical loupe.

After laparorrhaphy and recovery of anesthesia, the rats were returned to their cages. Ten $\mathrm{mg} / \mathrm{kg}$ of dipyrone was applied, intramuscularly, for analgesia. The animals received water and commercial standard food ad libitum until the measurement experiment date.

Euthanasia was performed with a lethal dose of thionembutal, intraperitoneally $(120 \mathrm{mg} / \mathrm{kg})^{10}$. 


\section{Blood pressure measurement}

The hypertension was confirmed on the third post operative day by measurement of mean arterial pressure (MAP) in the $\mathrm{C} 3$ and E3 groups by invasive method as previously described by Sordi et al. ${ }^{11}$. Briefly, under anesthesia (as above), heparinized PE-20 and PE-50 polyethylene catheters were inserted into the left femoral vein for drug injection and into the right carotid artery for recording of blood pressure respectively. To prevent clotting, a bolus dose of heparin (300 IU) was injected immediately after vein cannulation. Animals were allowed to breathe spontaneously via a tracheal cannula. Body temperature was monitored by a rectal thermometer and maintained at $37 \pm 1^{\circ} \mathrm{C}$ by means of a heating table. After the surgical procedure, a period of $30 \mathrm{~min}$ was allowed for stabilization and then systolic and diastolic arterial blood pressure were recorded for $30 \mathrm{~min}$. Blood pressure data were recorded with a catheter pressure transducer coupled to a Powerlab 8/30 (AD Instruments Pty Ltd., Castle Hill, Australia).

\section{Angiotensin II quantification}

The quantification of Angiotensin II was performed using the ELISA method (Enzyme Linked Immuno Sorbent Assay), following the RayBio ${ }^{\circledR}$ Human Angiotensin II EIA Kit Protocol. The plasma was collect after cardiac puncture. The range of read was $450 \mathrm{~nm}$ in a Life Lab MX PN 2001 ELISA reader.

Third, 7 or 14 days after surgical procedure, animals were killed with a lethal dose of thionembutal, intraperitoneally $(120 \mathrm{mg} / \mathrm{kg})$. A new laparotomy was performed and evaluated for the presence of free fluid and the quality of it, abscess, anastomotic dehiscence and adhesions to it. The adhesions were classified, when present, as the engagement of the circumference of the anastomosis in up to $50 \%$ and more than $50 \%$.

\section{Burst pressure}

A segment of colon measuring four centimeters in length, with centrally anastomosis has been removed without breaking any adhesion.

Anastomosis pressure resistance was measured by the inflation of $0.5 \mathrm{l} / \mathrm{min}$ of oxygen ${ }^{12}$. It was considered as resistance to inflation, the pressure recorded at the time of exhaust gas by the anastomosis or the intestinal wall.

\section{Histological study}

The intestinal pieces were embedded in paraffin; the sections were obtained with five micrometers of thickness stained with hematoxylin-eosin in which the epithelialization complete (when there was epithelial coverage against both edges of the wound) or incomplete, the inflammatory reaction and the organization of the layers of the intestinal wall disorganized (when there isn't continuity of the muscle layer, or were misaligned), organizing and organized (when presented as arranged in line, even without complete muscle regeneration).

The inflammatory reaction was assessed by the presence of polymorphonuclear infiltrate and monomorfonuclear, edema with vascular congestion, the degree of granulation tissue formation and fibrosis. The data were classified as sharp, moderate, slight or absent and transformed into quantitative variables (Table 1).

TABLE 1 - Index attributed to inflammatory parameters in histological analysis.

\begin{tabular}{ccccc}
\hline & \multicolumn{4}{c}{ INTENSITY } \\
\cline { 2 - 5 } Inflammatory index & Sharp & Moderate & Slight & Absent \\
\hline Polymorphonuclear & -3 & -2 & -1 & 0 \\
Edema & -3 & -2 & -1 & 0 \\
Congestion & -3 & -2 & -1 & 0 \\
Monomorphonuclear & 3 & 2 & 1 & 0 \\
Granulation Tissue & 3 & 2 & 1 & 0 \\
Fibrosis & 3 & 2 & 1 & 0 \\
\hline
\end{tabular}

Vizzotto Junior et al. ${ }^{13}$

The sum of these indices established a score of inflammation for each anastomosis. The median of the scores allowed classification into three sub phases of the inflammatory process (Table 2).

TABLE 2 - Inflammatory phase classification process in accordance with the final score for each group.

\begin{tabular}{cc}
\hline Inflammatory phase & Final score classification \\
\hline Acute & -9 a -3.1 \\
Sub-acute & $-3 *$ a 3 \\
Chronic & 3.1 a 9 \\
\hline
\end{tabular}

Vizzotto Junior et al..$^{13 *}$ modified

Picro Sirius stain allowed the identification of the density of collagen in wounds, differed collagen III and collagen I, in polarized light. Images were captured with 200x magnification, were analyzed by the software Image-Pro Plus ${ }^{\circledR}$ for Windows 4.5 (Media, MD, Cybernetics, Silver Spring USA) by measuring the area occupied by collagen. It was read five fields and obtained the 
average percentage of area occupied by collagen and this gave the percentage of collagen III and I.

\section{Statistical analysis}

The results were analyzed with the software SPSS v.14.0. The Student T test for independent samples or the nonparametric Mann-Whitney test when appropriate were used for group comparisons with regard to quantitative variables. The condition of normality of variables was assessed by the Shapiro-Wilk test and homogeneity of variances by Levene test. For dichotomous qualitative variables we used the Fisher exact test. All tests were bilateral and $p \leq 0.05$ were considered statistically significant.

\section{Results}

The MAP in the control group was $74.0 \pm 11.5 \mathrm{mmHg}$ and in the experimental group was $136.3 \pm 13.2 \mathrm{mmHg}(\mathrm{p}<0.001)$.

The quantification of angiotensin II in the control group (C3, C7 and C14) showed a mean $2.61 \pm 1.39 \mathrm{ng} / \mathrm{ml}$ and in the experimental group (E3, E7 and E14) showed a mean $2.53 \pm 0.49$ $\mathrm{ng} / \mathrm{ml}(\mathrm{p}=0.807)$.

Infections in the abdominal wall, peritonitis or dehiscence of the skin were not observed. There was no difference in incidence of intraperitoneal abscess, adhesions to the anastomosis and the extent of adherence to the anastomosis between sub-groups.

The burst pressure was not significantly different on the

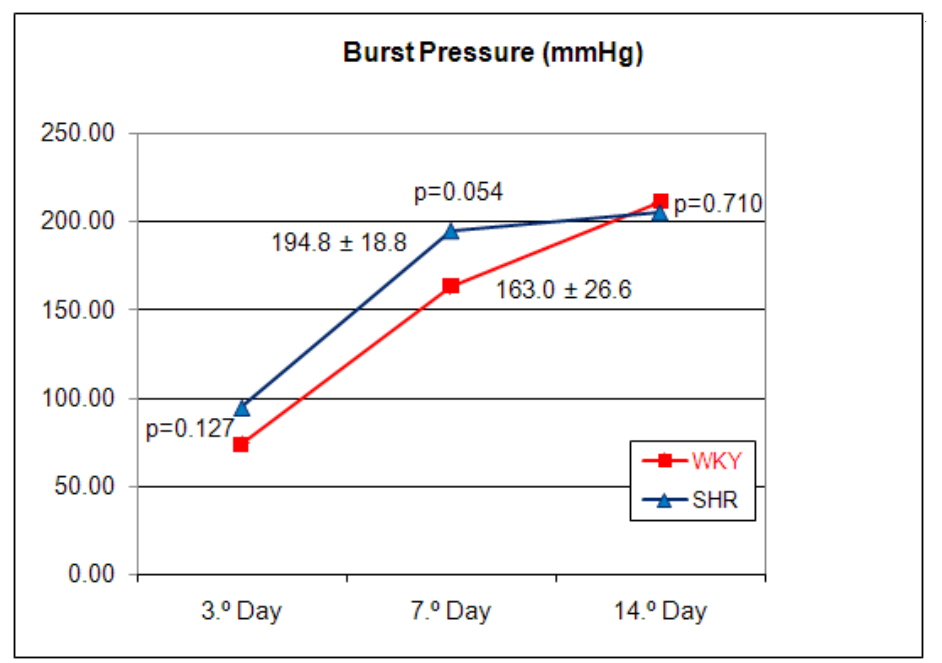

FIGURE 1 - Burst pressure of three different times in control and experimental groups, with $\mathrm{p}$ values in the comparison between groups.

When testing the resistance of the anastomosis, the rupture occurred on the third day on it and in other sub-groups showed no statistical difference between the rupture of the anastomosis and the bowel wall.

The presence of intramural abscess, edema, vascular congestion, granulation tissue and mononuclear cells showed no significant difference.

The evolution of epithelialization of the anastomosis was similar in both groups, as well as the organization of the coats of the intestinal wall.

Polymorphonuclear cells were more numerous in the control group on the third day $(\mathrm{p}=0.028)$ and at other times in similar amount in both groups.

The inflammatory process was more intense on the third day in the control group $(\mathrm{p}=0.023)$ and similar in other times (Table 3).

TABLE 3 - Classification of the inflammatory process in the anastomoses of the control and experimental groups in the third, seventh and fourteenth days.

\begin{tabular}{cccc}
\hline Group & Median & Inflammatory & \\
C3 & -6 & Acute & $\mathrm{p}=0.023$ \\
E3 & -3 & Sub-acute & \\
C7 & 2 & Sub-acute & $\mathrm{p}=0.450$ \\
E7 & 3 & Sub-acute & \\
C14 & 4 & Chronic & $\mathrm{p}=0.605$ \\
E14 & 4 & Chronic & \\
\hline
\end{tabular}

Collagen density was not significantly different between control and experimental groups in the third, seventh and fourteenth days $[\mathrm{C} 3=2.4, \mathrm{E} 3=1.6(\mathrm{p}=0.195), \mathrm{C} 7=3.46, \mathrm{E} 7=3.53$ $(p=0.779), C 14=4.56, E 14=4.33(p=0.863)]$ and sub-fractions III and I collagen (Figures 2 and 3 ).

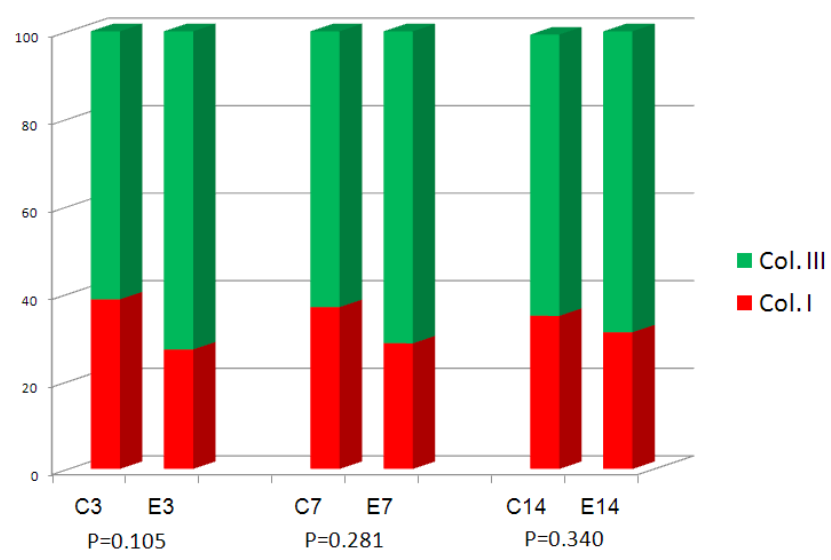

FIGURE 2 - Demonstrating the mean concentrations of total collagen by sub-group and it's fractions. 

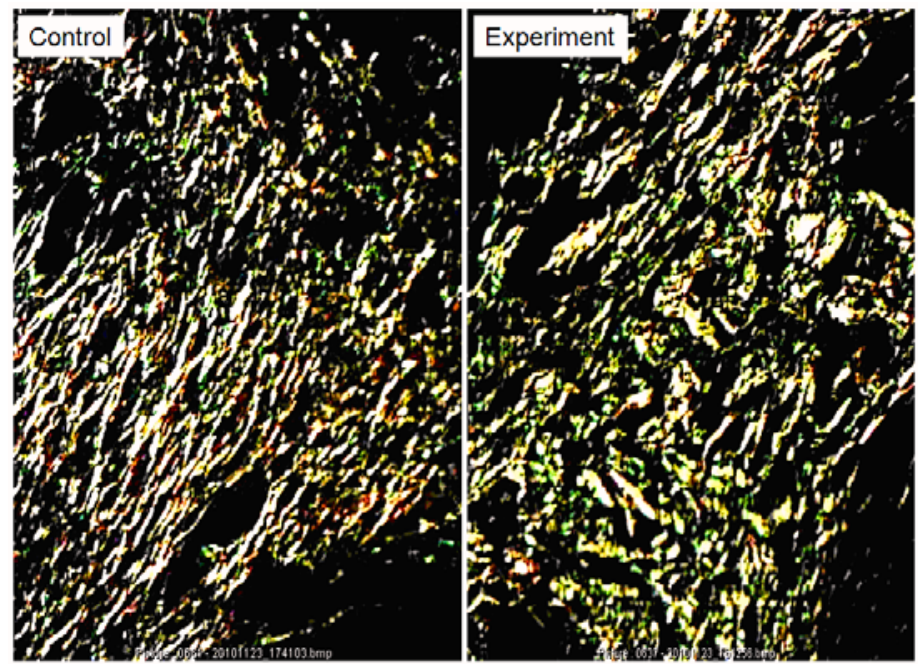

FIGURE 3 - Histological photomicrograph sections of animal colon anastomosis, on the fourteenth day after surgery, which shows the type I collagen (yellow to red) and collagen III (green) (Sirius Picro polarized light - 200x)

\section{Discussion}

The choice of spontaneously hypertensive rats (SHR) is its similarity with essential hypertension in human ${ }^{14}$, whereas in animals with induced hypertension, angiotensin is elevated, which could interfere with the results, since angiotensin II is involved in the healing process, both in a systemic way, as local ${ }^{15}$.

Despite the lower concentration of collagen, the aging did not increase the risk of left colon anastomoses in Wistar rats ${ }^{12,16}$, nevertheless, still turned away from the influence of aging on the anastomosis studied, opting for the young animals.

The abdominal wound healing has not been influenced by hypertension, assessed by tensile strength and hydroxyproline content in rats $\mathrm{SHR}^{17}$. In male Wistar rats with induced hypertension showed lower tensile strength of the abdominal wall in the hypertensive treated with losartan compared with controls ${ }^{18}$.

The control animals were WKY. The SHR are derived from a blood cross of co-WKY animals, making them a natural control for SHR rats.

A retrospective study conducted by Fawcett et al. ${ }^{19}$ observed the association of risk factors for macrovascular disease, the presence of microvascular disease in the colon and colonic anastomosis dehiscence. Fifty percent of patients who developed anastomotic dehiscence were hypertensive under treatment, compared with $20 \%$ who were not hypertensive.

The pressure level of hypertensive rats in this experiment was lower than that observed in the literature ${ }^{14,17,20}$. This difference in value was probably due to the fact that they were obtained in anesthetized rats rather other authors that had obtained it with the conscious rats.

Hypertension in SHR rats have genetic origin and multifactorial. Schleiffer et $a .^{21}$ observed that the parathyroid glands are necessary for the installation process of arterial hypertension. Hashimoto et l. $^{22}$ suggested that the corticosteroid is essential for the development of arterial hypertension. Unger et $a l .{ }^{23}$ said that the increased sympathetic activity and exaggerated reaction of the smooth muscle in SHR rats, genetic factors often cited as being particularly active during the development of hypertension, would be less important after hypertension is established and that the renin-angiotensin system would constitute only one of several factors involved in genetic hypertension. Norrelund et al. ${ }^{24}$ concluded that the distal stenosis of the afferent arteriole at the age of 7 weeks contributes to the subsequent development of arterial hypertension. Reckelhoff et al. ${ }^{25}$ suggests that hypertension is mediated by the renin-angiotensin system.

The angiotensin II accelerates the proliferation, migration and growth factor production by vascular endothelial cells. Although it is suggested that angiotensin II has pro-angiogenic effect, its involvement and activation of the AT1 receptor on the healing needs further study. Kurosaka et al. ${ }^{26}$ observed that the AT1a receptor activation enhances the expression of vascular endothelial growth factor (VEGF) and the formation of granulation tissue. Also, the AT1 receptor antagonists are commonly used as therapeutic agents, and patients who are using it may experience delayed healing.

In this study the determination of plasma angiotensin II was not significantly different, demonstrating that it did not interfere with data analysis.

The Laplace's law (The larger the vessel radius, the larger the wall tension required to withstand a given internal fluid pressure), explains the rupture outside the anastomosis site, seen most often in groups C14 and E14. Anastomosis is the site which has smaller radius, so it has a higher resistance to the intestinal wall ${ }^{27}$. Biondo-Simões et al. ${ }^{12}$ evaluated the healing of colonic Wistar rats with a mean age of 110 days and 762 days. Bowel suture held an inch from the peritoneal reflection and observed that the rupture occurred at the anastomosis on the third day after surgery. Although, rupture in the intestinal wall occurred on the seventh, tenth-fourth and twenty-first day after surgery.

The rupture pressure is influenced by the rate of inflation of the air or fluid in the isolated intestinal segment and if the adhesions were preserved or not ${ }^{27}$. In this study, $\mathrm{O}_{2}$ flow was constant at $0.5 \mathrm{l} / \mathrm{min}$ and the adhesions were preserved in the intestinal segment removed to measure the rupture pressure.

The absence of evidence from studies of colonic healing 
in SHR rats in the literature, we chose to compare the Wistar animals, used as control of other studies with our control (WKY).

Greca et al. ${ }^{28}$ obtained mean rupture pressure of 169.7

$\mathrm{mmHg}$ on the seventh day after surgery. Ugurlu et al. ${ }^{29}$ assessed mean rupture pressure equal to $43 \pm 2.09$ and $169.7 \pm 3.18 \mathrm{mmHg}$, respectively in the third and seventh days postoperatively in the control group. Bezerra et al. ${ }^{30}$ on the third day after surgery, measured $25.4 \pm 14.1 \mathrm{mmHg}$ and $187.3 \pm 39.5 \mathrm{mmHg}$ on the seventh day. Biondo-Simões et al. ${ }^{16}$ identified strength of the anastomosis of $50 \mathrm{mmHg}$ on the third day, the seventh day $180 \mathrm{mmHg}$ and 230 $\mathrm{mmHg}$ on the fourteenth day of the colonic anastomosis. Nassif Thá et $a l .{ }^{31}$ found mean rupture pressure of $168.7 \mathrm{mmHg}$ on the seventh postoperative day. Cakmak et al. ${ }^{32}$ observed burst pressure in vivo, on the third day of $90.1 \pm 22 \mathrm{mmHg}$ and the seventh day of $220.12 \pm 35.15 \mathrm{mmHg}$.

Colonic anastomosis in Wistar rats, males and young, Biondo-Simões et al. ${ }^{33}$ indentified complete epithelialization on the fourteenth postoperative day. Biondo-Simões et al. ${ }^{12}$ observed that epithelialization was complete on the fourteenth day after posteoperative day and that in the twenty-first day was completely recovered, it is possible to identify the site of anastomosis only the discontinuity of the muscular layer.

Biondo-Simões et $a l .{ }^{33}$ observed that the coats of the intestinal wall were partially organized on the fourteenth postoperative colonic anastomoses of young rats.

The score of the inflammatory process in colonic anastomosis Wistar rats also was studied by Bezerra et al. ${ }^{30}$ They observed that $100 \%$ of the inflammatory processes in the acute phase were in the control group at the third postoperative day. On the seventh day, $60 \%$ were in the acute phase and $30 \%$ were in the subacute phase. The authors used for classification sub-acute in the range of the inflammatory process flows between -2.9 to +2.9 and in this study, we used the range between -3.0 and +3.0 .

Spevak et $a l .{ }^{34}$, on the fifth day after surgery, observed that the SHR had exudative process more prominent compared to normotensive controls, which prolonged the inflammation phase and showed a delay in the regeneration phase of healing. In this study, colonic anastomosis, occurred in the opposite way, where the experimental group on the third day after surgery showed subacute classification and control group were rated acute. However, polymorphonuclear infiltrate influenced acute phase score. These cells are not essential to the healing process and can slows $i^{35}$

Biondo-Simões et $a l{ }^{16,18}$ observed progressive gain of collagen in the anastomosis area on the fourth, seventh and fourteenth days after surgery for bowel suture in Wistar rats in the control group. Tostes et al. ${ }^{17}$ measured the concentration of hydroxyproline in the abdominal wall of SHR rats subjected to laparotomy, obtaining the progressive concentration of hydroxyproline, which is a good marker of the amount of collagen in tissue ${ }^{36}$, on the seventh and fourteenth day after surgery.

The proportion of collagen III in rats on the fourth, seventh and fourteenth days after surgery for bowel suture, in the control group was $19.0 \%, 22.8 \%$ and $23.8 \%$, respectively ${ }^{18}$. In another study, Biondo-Simões et al. ${ }^{16}$ measured 17\%, 23\% and $33 \%$ for the third, seventh and fourteenth postoperative day.

The proportion of type I collagen in Wistar rats on the fourth, seventh and fourteenth days after surgery for bowel suture, in the control group was $27.3 \%, 26.7 \%$ and $31.3 \%$, respectively ${ }^{18}$. In another study the proportion was $10 \%, 15 \%$ and $29 \%$ on the third, seventh and fourteenth day after surgery, respectively ${ }^{16}$.

\section{Conclusion}

Hypertension did not affect significantly the healing process of anastomoses of the left colon in rats in this experiment.

\section{References}

1. Thornton FJ; Barbul A. Healing in the gastrointestinal tract. Surg Clin North Am. 1997;77(3):549-73.

2. Takeda H, Katagata Y, Hozumi Y, Kondo S. Effects of angiotensin II receptor signaling during skin wound healing. Am J Pathol. 2004;165(5):1653-62.

3. Fujiyama S, Matsubara H, Nozawa Y, Maruyama K, Mori Y, Tsutsumi Y, Masaki H, Uchiyama Y, Koyama Y, Nose A, Iba O, Tateishi E, Ogata N, Jyo N, Higashiyama S, Iwasaka T. Angiotensin AT1 and AT2 receptors differentially regulate angiopoietin-2 and vascular endothelial growth factor expression and angiogenesis by modulating heparin binding-epidermal growth factor (EGF)mediated EGF receptor transactivation. Circ Res. 2001; 88:22-9.

4. Instituto Brasileiro de Geografia e Estatística. Rio de Janeiro: Ministério do Planejamento, Orçamento e Gestão. Disponível em http://www.ibge.gov.br/home/presidencia/noticias/noticia visualiza.php?id_noticia $=1272 \&$ id pagina

5. Gus I, Harzheim E, Zaslavsky C, Medina C, Gus M. Prevalência, reconhecimento e controle da hipertensão arterial sistêmica no Estado do Rio Grande do Sul. Arq Bras Cardiol. 2004;83(5):424-8. Available from http://www.scielo.br.ez82.periodicos.capes.gov.br/scielo. php?script=sci_arttext\&pid=S0066-782X2004001700009\&lng=en. doi: 10.1590/S0066-782X2004001700009.

6. Centers for Disease Control and Prevention (CDC). State-specific trends in self-reported blood pressure screening and high blood pressure - United States, 1991-1999. MMWR Morb Mortal Wkly Rep. 2002;51(21):456-60

7. Instituto Nacional do Câncer. Rio de Janeiro: Ministério da Saúde; 1996. Disponível em http://mortalidade.inca.gov.br/Mortalidade/ prepararModelo01.action

8. Instituto Nacional do Câncer. Rio de Janeiro: Ministério da Saúde; 1996. Disponível em http://www1.inca.gov.br/estimativa/2012/ tabelaestados.asp? $\mathrm{UF}=\mathrm{BR}$ 
9. A relevância do câncer colorretal. Grupo Técnico de Avaliação e Informações de Saúde. Secretaria de Estado da Saúde. São Paulo, Brasil. Bepa. 2009;6(68):1-14.

10. Brasil. Resolução No 714 de 20 de junho de 2002. Dispõe sobre procedimentos e métodos de eutanásia em animais, e dá outras providências. Diário Oficial da União, Brasília, p.201, 21 de jun. 2002.

11. Sordi R, Fernandes D, Heckert BT, Assreuy J. Early potassium channel blockade improves sepsis-induced organ damage and cardiovascular dysfunction. Br J Pharmacol. 2011;163(6):1289-301.

12. Biondo-Simões MLP, Ioshii SO, Kimura L, Martynetz F, Lemos M, Borsato KS. Effect of aging on the healing of colonic anastomoses in rats. Acta Cir Bras. 2004;19(2):89-93. Available from URL: http://www.scielo.br/acb.

13. Vizzotto Junior AO, Noronha L, Scheffel DLH, Campos ACL. Influência da cisplatina administrada no pré e no pós-operatório sobre a cicatrização de anastomoses colônicas em ratos. J Bras Patol Med Lab. 2003;39(2):143-9. Disponível em http://www.scielo.br/scielo. php?script $=$ sci_arttext\&pid $=$ S1676-24442003000200009\&lng $=$ en doi: 10.1590/S1676-24442003000200009.

14. Valenti VE, Ferreira C, Meneghini A, Ferreira M, Murad N, Ferreira Filho C, Correa JA, Abreu LC, Colombari E. Avaliação da função barorreflexa em ratos jovens espontaneamente hipertensos. Arq Bras Cardiol. 2009;92(3):216-21. Disponível em http://www.scielo.br/scielo.php?script=sci_arttext\&pid=S0066782X2009000300009\&lng=en. doi: 10.1590/S0066$782 X 2009000300009$.

15. Weber KT. Fibrosis, a common pathway to organ failure: angiotensin II and tissue repair. Semin Nephrol. 1997;17(5):467-91.

16. Biondo-SimõesMLP,Biondo-Simões R, IoshiiSO,BarczakDS, Tetilla MR. Effects of hyperglycemia and ageing on the healing of colonic anastomoses in rats. Acta Cir Bras. 2009;24(2):136-43. Available from http://www.scielo.br.ez82.periodicos.capes.gov.br/scielo. php?script=sci_arttext\&pid=S0102-86502009000200011\&lng=en. doi: $10.1590 / \mathrm{S} 0102-86502009000200011$.

17. Tostes JM, Watanabe AL, Watanabe LM. Effects of hypertension on abdominal wall healing: experimental study in rats. Surg Today. 2007;37(3):215-9.

18. Biondo-Simões MLP, Zazula AD, Gomes AB, Poncio C, Torres LF, Borsato KS. Influence of arterial hypertension treated with losartan on skin healing in rats. Acta Cir Bras. 2006;21(3):144-50.

19. Fawcett A, Shembekar M, Church JS, Vashisht R, Springall RG, Nott DM. Smoking, hypertension, and colonic anastomotic healing; a combined clinical and histopathological study. Gut. 1996;38:7148 .

20. Harrap SB, Van der Merwe WM, Griffin SA, Macpherson F, Lever AF. Brief angiotensin converting enzyme inhibitor treatment in young spontaneously hypertensive rats reduces blood pressure longterm. Hypertension. 1990;16(6):603-14.

21. Schleiffe R, Berthelot A, Pernot F, Gairard A. Parathyroids, thyroid and development of hypertension in SHR. Jpn Circ J. 1981;45(11):1272-9.

22. Hashimoto K, Makino S, Hirasawa R, Takao T, Sugawara M, Murakami K, Ono K, Ota Z. Abnormalities in the hypothalamopituitary-adrenal axis in spontaneously hypertensive rats during development of hypertension. Endocrinology. 1989;125(3):116167.

23. Unger T, Rettig R. Development of genetic hypertension. Is there a "critical phase"? Hypertension. 1990;16(6):615-6.

24. Norrelund H, Christensen KL, Samani NJ, Kimber P, Mulvany MJ, Korsgaard N. Early narrowed afferent arteriole is a contributor to the development of hypertension. Hypertension. 1994;24(3):301-8.

25. Reckelhoff JF, Zhang H, Srivastava K. Gender differences in development of hypertension in spontaneously hypertensive rats: role of the renin-angiotensin system. Hypertension. 2000;35[part 2]:480-3.

26. Kurosaka M, Suzuki T, Hosono K, Kamata Y, Fukamizu A, Kitasato H, Fujita Y, Majima M. Reduced angiogenesis and delay in wound healing in angiotensin II type 1a receptor-deficient mice. Biomed Pharmacother. 2009;63:627-34.

27. Koruda MJ, Rolandelli RH. Experimental studies on the healing of colonic anastomoses [review]. J Surg Res. 1990;48(5):504-15.

28. Greca FH, Biondo-Simões MLP, Ioshi S, Santos EAA, Chin EWK, El Tawil II, Stalhschmidt FL. Cicatrização de anastomoses do cólon esquerdo com doença inflamatória: estudo experimental em ratos. Acta Cir Bras. 2000;15(Supl 3):41-6.

29. Ugurlu L, Turan M, Canbay E, Elagöz S, Sen M. Effect of nifedipine on the healing of left colonic anastomoses in rats. Surg Today. 2003;33:902-8.

30. Bezerra JAF, Campos ACL, Vasconcelos PRL, Nicareta JR, Ribeiro ER, Sebastião APM, Urdiales AIA, Moreira M, Borges AM. Extrato de Passiflora edulis na cicatrização de anastomose colônica em ratos: estudo morfológico e tensiométrico. Acta Cir Bras. 2006;21(Supl 3):16-25. Disponível em http://www.scielo.br/acb

31. Thá Nassif AC, Greca FH, Graf H, Repka JCD, Nassif LS. Wound healing in colonic anastomosis in hypothyroidism. Eur Surg Res. 2009;42:209-15.

\section{Correspondence:}

Gilberto Luiz Ortolan

Avenida Anita Garibaldi, 1555/11

84015-902 Ponta Grossa - PR Brasil

Tel.: (55 42)3222-3233

gilbertoortolan@gmail.com

Received: March 22, 2012

Review: May 23, 2012

Accepted: June 21, 2012

Conflict of interest: none

Financial source: none

${ }^{1}$ Research performed at Experimental Laboratory, Ponta Grossa State University (UEPG). Part of Master degree thesis, Postgraduate Program in Surgery, Pontificial Catholic University of Parana (PUCPR), Brazil.

Tutor: Prof. Maria de Lourdes Pessole Biondo-Simões. 